\title{
Metals and Metallurgy
}

ISSN: 2578-0255

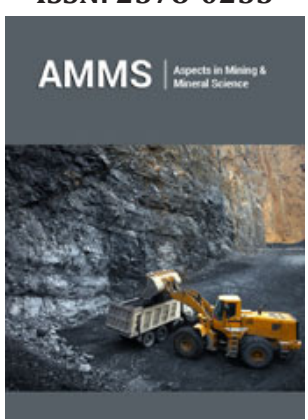

*Corresponding author: Fathi Habashi, Department of Mining, Metallurgical and Materials Engineering, Laval University, Canada

\section{Submission: 制 March 20, 2019}

Published: 觜May 29, 2019

Volume 3 - Issue 1

How to cite this article: Fathi H. Metals and Metallurgy. Aspects Min Miner Sci.3(1). AMMS.000551.2019. DOI: 10.31031/AMMS.2019.03.000551.

Copyright@ Fathi Habashi, This article is distributed under the terms of the Creative Commons Attribution 4.0 International License, which permits unrestricted use and redistribution provided that the original author and source are credited.

\section{Fathi Habashi*}

Department of Mining, Metallurgical and Materials Engineering, Canada

\section{The Commercial Classification of Metals}

Elements can be arranged conveniently in the Periodic Table and described as metals, non-metals, and metalloids. Metals are further classified as typical and less typical, transition and inner transition (Figure 1). While this classification is useful for the chemists and physicists it does not show the economic value of the metals. For the metallurgist however, a more useful form is the commercial classification of metals: ferrous and nonferrous (Figure 2). This classification is well justified because the annual production of iron and steel in one year exceeds the production of all other metals combined in about ten years. Ferrous metals include wrought iron, cast iron, and steel. Nonferrous metals, on the other hand, is classified into primary, secondary, light, precious, etc., as shown in (Table 1).

Table 1: Commercial classification of nonferrous metals and metalloids.

\begin{tabular}{|c|c|c|}
\hline Group & Metals & Remarks \\
\hline Primary & $\mathrm{Cu}, \mathrm{Pb}, \mathrm{Zn}, \mathrm{Sn}, \mathrm{Ni}$ & Extensively used; second in importance to iron. \\
\hline Secondary & As, $\mathrm{Sb}, \mathrm{Bi}, \mathrm{Cd}, \mathrm{Hg}$, Co & $\begin{array}{l}\text { Mainly by-products of the major metals but also form } \\
\text { their own deposits. Used in almost equal amounts (10- } \\
20 \text { thousand tons annually). }\end{array}$ \\
\hline Light & $\mathrm{Be}, \mathrm{Mg}, \mathrm{Al}, \mathrm{Ti}$ & $\begin{array}{l}\text { Low specific gravity (below } 4.5 \text { ), used mainly as mate- } \\
\text { rial of construction. }\end{array}$ \\
\hline Precious & $\begin{array}{l}\mathrm{Au}, \mathrm{Ag}, \mathrm{Pt}, \mathrm{Os}, \mathrm{Ir}, \mathrm{Ru} \\
\text { Rh, Pd }\end{array}$ & Do not rust; highly priced. \\
\hline Refractory & $\begin{array}{l}\text { W, Mo, Nb, Ta, Ti, Zr, } \\
\text { Hf, V, Re, Cr }\end{array}$ & $\begin{array}{l}\text { Melting points above } 1650^{\circ} \mathrm{C} \text {. Mainly used as alloying } \\
\text { elements in steel but also used in the elemental form. } \\
\text { Some resist high temperature without oxidation. }\end{array}$ \\
\hline Scattered & $\begin{array}{l}\text { Sc, Ge, Ga, In, Tl, Hf, } \\
\text { Re, Se, Te }\end{array}$ & $\begin{array}{l}\text { Do not form minerals of their own. Distributed in } \\
\text { extremely minute amounts in the earth's crust. }\end{array}$ \\
\hline Radioactive & $\begin{array}{l}\text { Po, Ra, Ac, Th, Pa, } \\
\text { U, Pu }\end{array}$ & $\begin{array}{c}\text { Undergo radioactive decay. Some of them }(\mathrm{U}, \mathrm{Pu} \text {, and } \\
\text { Th) undergo fission. Plutonium prepared artificially in } \\
\text { nuclear reactors. }\end{array}$ \\
\hline $\begin{array}{l}\text { Rare earths (lantha- } \\
\text { nides) }\end{array}$ & $\begin{array}{l}\text { Y, La, Ce, Pr, Nd, Sm, } \\
\text { Eu, Gd, Tb, Dy, Ho, } \\
\text { Er, Tm, Yb, Lu }\end{array}$ & $\begin{array}{l}\text { Always occur together, similar chemical properties. Not } \\
\text { rare as the name implies. }\end{array}$ \\
\hline Ferroalloy & Cr, Mn, Si, B & $\begin{array}{l}\text { Were once mainly used as alloying elements to steel, } \\
\text { but now also used in elemental form. }\end{array}$ \\
\hline Alkali & $\mathrm{Li}, \mathrm{Na}, \mathrm{K}, \mathrm{Rb}, \mathrm{Cs}$ & Soft and highly reactive. \\
\hline Alkaline earths & $\mathrm{Be}, \mathrm{Mg}, \mathrm{Ca}, \mathrm{Sr}, \mathrm{Ba}$ & $\begin{array}{l}\text { Beryllium is more similar to aluminum, and magne- } \\
\text { sium is more similar to lithium (Diagonal similarities) }\end{array}$ \\
\hline
\end{tabular}




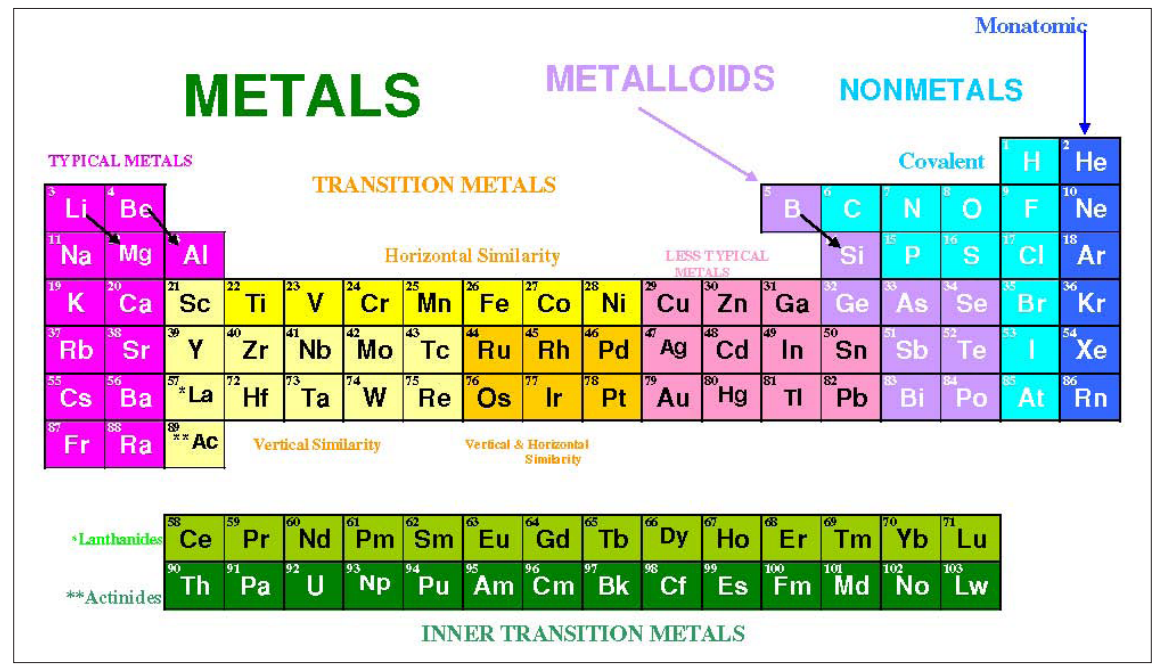

Figure 1: Periodic table showing metals, nonmetals, and metalloids and the different types of metals.

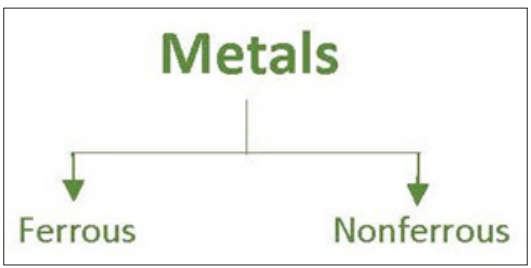

Figure 2: Ferrous and nonferrous metals.

\section{Discovery of Metals}

Seven metals were used by the ancient people, then in the Middle Ages the alchemists knew aqua regia for dissolving gold and in the $13^{\text {th }}$ and $14^{\text {th }}$ centuries three metalloids: arsenic, antimony, and bismuth were discovered. The East supplied two metals: zinc and boron in form of borate. The bulk of metals became known in the $17^{\text {th }}$ and $18^{\text {th }}$ centuries.

\section{Smelting}

In the $17^{\text {th }}$ century, attempts were made to understand the nature of fire and the smelting process. It was once believed that when coal was burnt, phlogiston which in Greek means flame [1], was released and a calx, that is, ash remained. If an ore or an oxide was heated with coal it takes up the escaping phlogiston in the fire to form the metal:

\section{Ore (oxide)+Phlogiston (from coal) $\rightarrow$ Metal}

It was the French chemist Antoine Laurent Lavoisier (17431794) who in 1772 finally directed the fatal blow to the theory, when a few years earlier oxygen was discovered, and he interpreted the phenomenon of combustion as an oxidation process.

\section{Tools of Discovery}

The platinum metals became known in Europe from Ecuador in South America and this was followed by many other metals (Table 2). The blowpipe (Figure 3) played an important role in the discovery. In the $19^{\text {th }}$ century the metals discovered was a result of the discovery of electric current and the development in analytical chemistry and chemical theory.
Table 2: Metals discovered in the eighteenth century.

\begin{tabular}{|c|c|c|c|}
\hline Year & Metal & Discoverer & Remarks \\
\hline 1735 & Cobalt & Brandt & Discovered in Sweden \\
\hline 1741 & $\begin{array}{l}\text { Plati- } \\
\text { num }\end{array}$ & Wood & Metal from South America \\
\hline 1745 & Boron & Bergman & $\begin{array}{l}\text { Metal from the East. Isolated in } 1808 \text { by } \\
\text { Gay-Lussac, Thénard, and Davy }\end{array}$ \\
\hline 1746 & Zinc & Marggraff & Metal from the East \\
\hline 1751 & Nickel & Cronstedt & Discovered in Sweden \\
\hline 1753 & $\begin{array}{l}\text { Bis- } \\
\text { muth }\end{array}$ & Geoffrey & Metalloid of the alchemists \\
\hline 1774 & $\begin{array}{l}\text { Manga- } \\
\text { nese }\end{array}$ & Ghan & Discovered in Sweden \\
\hline 1781 & $\begin{array}{l}\text { Molyb- } \\
\text { denum }\end{array}$ & Hjelm & Discovered in Sweden \\
\hline 1782 & $\begin{array}{l}\text { Telluri- } \\
\text { um }\end{array}$ & $\begin{array}{l}\text { Müller von } \\
\text { Reichen- } \\
\text { stein }\end{array}$ & $\begin{array}{l}\text { Isolated by Müller von Reichenstein but } \\
\text { not named. Named in } 1798 \text { by Klaproth }\end{array}$ \\
\hline 1783 & $\begin{array}{l}\text { Tung- } \\
\text { sten }\end{array}$ & $\begin{array}{l}\text { Elhujar } \\
\text { brothers }\end{array}$ & Discovered in Spain \\
\hline 1789 & $\begin{array}{l}\text { Urani- } \\
\text { um }\end{array}$ & Klaproth & $\begin{array}{l}\text { Klaproth believed that he prepared ura- } \\
\text { nium metal when he reduced } \mathrm{U}_{3} 0_{8} \text { with } \\
\text { carbon. Infact he obtained only a lower } \\
\text { oxide }\left(\mathrm{UO}_{2}\right) \text {. The metal was isolated by } \\
\text { Peligot in } 1841 \text { by the reduction of } \mathrm{UCl}_{4} \\
\text { with potassium }\end{array}$ \\
\hline 1789 & $\begin{array}{l}\text { Zirconi- } \\
\text { um }\end{array}$ & Klaproth & $\begin{array}{l}\text { Isolated by Berzelius in } 1824 \text { by the } \\
\text { reduction of the fluoride with sodium }\end{array}$ \\
\hline
\end{tabular}




\begin{tabular}{|c|c|c|c|}
\hline 1791 & $\begin{array}{c}\text { Titani- } \\
\text { um }\end{array}$ & Gregor & $\begin{array}{r}\text { Isolated by Berzelius in 1824 (impure } \\
\text { metal), Nilson and Pettersson in 1887 } \\
\text { (95\% pure), and by Hunter in 1910 } \\
\text { (99.9\% pure). }\end{array}$ \\
\hline 1794 & Yttrium & Gadolin & Discovered in Sweden \\
\hline 1797 & $\begin{array}{c}\text { Berylli- } \\
\text { um }\end{array}$ & Vauquelin & $\begin{array}{r}\text { Isolated by Wöhler and Bussy in 1828 } \\
\text { by the reduction of the fluoride with } \\
\text { sodium. }\end{array}$ \\
\hline 1797 & $\begin{array}{c}\text { Chro- } \\
\text { mium }\end{array}$ & Vauquelin & $\begin{array}{r}\text { Isolated by Wöhler in 1859 by reducing } \\
\text { molten chromium chloride with zinc }\end{array}$ \\
\hline
\end{tabular}

It was Robert Bunsen (1811-1899) at the University of Heidelberg, who paved the way for the great discoveries in the $19^{\text {th }}$ century (Table 3) with his invention of the burner in 1852 that carries his name and is found today in most chemical laboratories (Figure 4). This burner permitted higher temperature to be achieved in the laboratory when conducting a test. Before this burner [2] the flame of a candle or from alcohol was used. The Bunsen burner flame permitted performing the flame tests (Figure 5) and later spectroscopic analysis (Figures 6 \& 7).

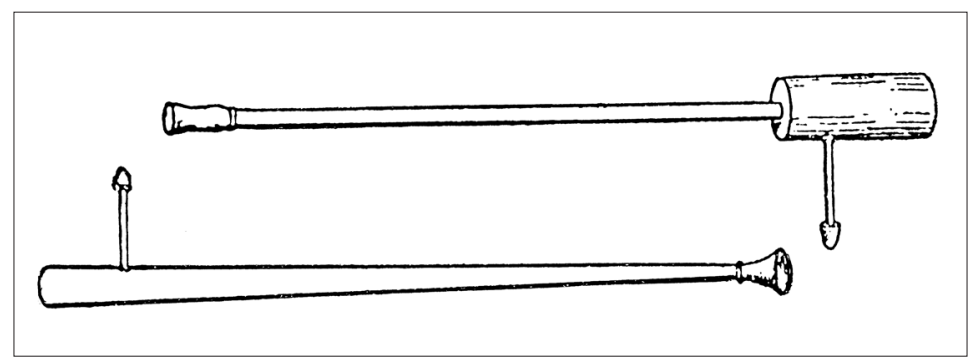

Figure 3: The blowpipe.

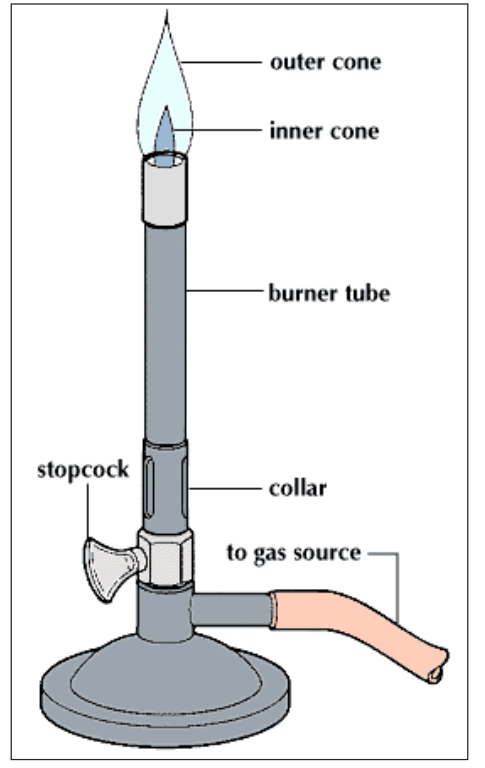

Figure 4: Bunsen burner.
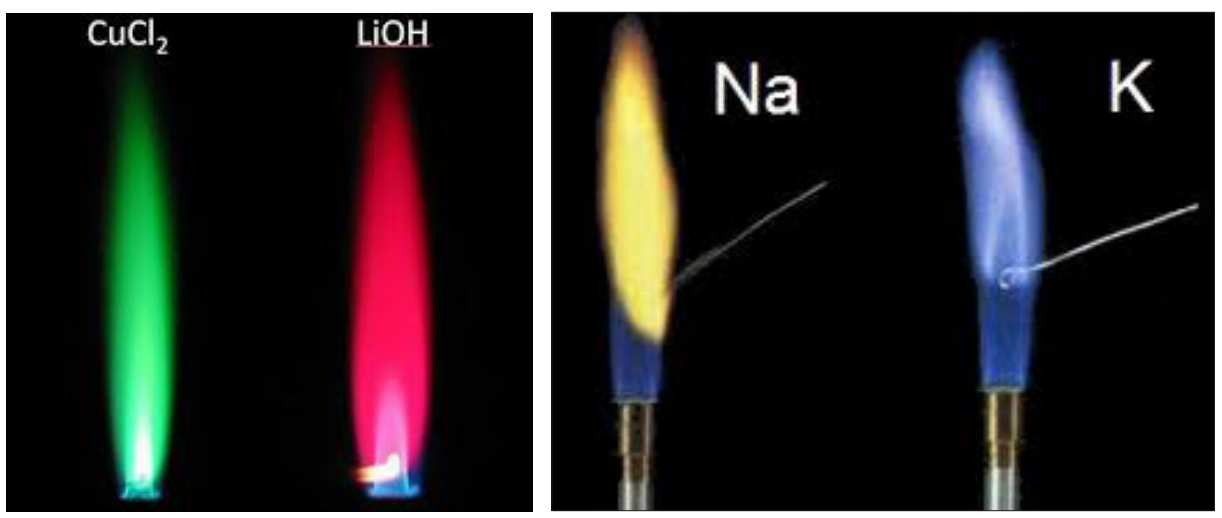

Figure 5: Examples of coloured flames in flame tests. 


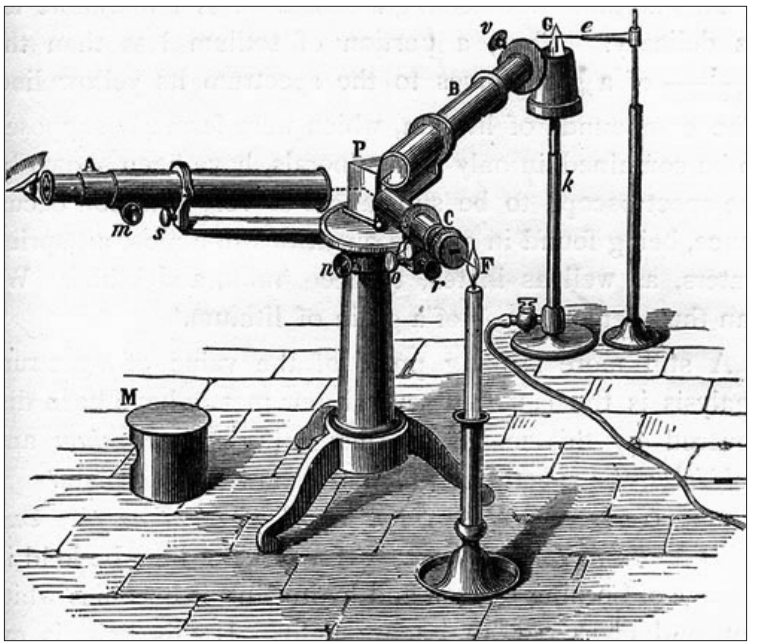

Figure 6: A first spectroscope.

\section{Calcium}

\section{Strontium}

\section{Barium}

Figure 7: Examples of emission spectra: calcium, strontium, and barium.

Table 3: Metals discovered and isolated in the nineteenth century.

\begin{tabular}{|c|c|c|c|}
\hline Year & Metal & Discoverer & Remarks \\
\hline 1801 & Niobium & Hatchett & $\begin{array}{l}\text { Isolated by Blomstrand in } 1864 \text { by reduction of } \mathrm{NbCl}_{5} \text { with } \mathrm{H}_{2} \text { and by Moissan in } 1901 \text { by } \\
\text { carbon reduction of } \mathrm{Nb}_{2} \mathrm{O}_{5} \text { in an electric furnace }\end{array}$ \\
\hline 1802 & Tantalum & Ekeberg & Discovered in Sweden \\
\hline \multirow{4}{*}{1803} & Iridium & Tennnat & Discovered in England \\
\hline & Osmium & & \\
\hline & Palladium & Wollaston & Discovered in England \\
\hline & Rhodium & & \\
\hline \multirow{2}{*}{1807} & Potassium & Davy & Discovered in England \\
\hline & Sodium & & \\
\hline \multirow{5}{*}{1808} & Boron & Gay-Lussac, Thenard, Davy & Discovered in France and England \\
\hline & Barium & Davy & Discovered in England \\
\hline & Calcium & Davy & Discovered in England \\
\hline & Magnesium & Davy & Discovered in England \\
\hline & Strontium & Davy & Discovered in England \\
\hline 1814 & Cerium & Berzelius & Isolated by Hillebrand and Norton in 1895 \\
\hline \multirow{3}{*}{1817} & Lithium & Arfwedson & Isolated by Davy in minute amounts, but in pure form by Arfwedson \\
\hline & Cadmium & Stromeyer & Discovered in Germany \\
\hline & Selenium & Berzelius & Discovered in Sweden \\
\hline
\end{tabular}




\begin{tabular}{|c|c|c|c|}
\hline 1823 & Silicon & Berzelius & Discovered in Sweden \\
\hline 1827 & Aluminum & Wöhler & Discovered in Germany \\
\hline 1828 & Thorium & Berzelius & Discovered in Sweden \\
\hline 1830 & Vanadium & Sofstrom & $\begin{array}{c}\text { Isolated by Roscoe in } 1869 \text { by } \mathrm{H}_{2} \text { reduction of } \mathrm{VCl}_{2} \text {. Prepared by Marden and Rich in } 1927 \\
\text { [purity 99.9\%] by reduction of the oxide with Ca }\end{array}$ \\
\hline 1839 & Lanthanum & Mosander & Discovered in Sweden \\
\hline \multirow{2}{*}{1843} & Erbium & Mosander & Discovered in Sweden \\
\hline & Terbium & Mosander & Discovered in Sweden \\
\hline 1844 & Ruthenium & Klaus & Discovered in Russia \\
\hline 1860 & Cesium & Bunsen and Kirchhoff & Discovered in Prussia \\
\hline \multirow{2}{*}{1861} & Rubidium & Bunsen and Kirchhoff & Discovered in Prussia \\
\hline & Thallium & Crookes & Discovered in England \\
\hline 1863 & Indium & Reich and Richter & Discovered in Germany \\
\hline 1875 & Gallium & de Boisbaudran & Discovered in France \\
\hline 1878 & Ytterbium & Marignac & Discovered in France \\
\hline \multirow{4}{*}{1879} & Samarium & de Boisbaudran & Discovered in France \\
\hline & Scandium & Nilson & Discovered in Sweden \\
\hline & Holmium & Cleve & Discovered in Sweden \\
\hline & Thulium & Cleve & Discovered in Sweden \\
\hline 1880 & Gadolinium & Marignac & Discovered in France \\
\hline \multirow{2}{*}{1885} & $\begin{array}{l}\text { Praseodym- } \\
\quad \text { ium }\end{array}$ & Auer von Welsbach & Discovered in Austria \\
\hline & Neodymuim & Auer von Welsbach & Discovered in Austria \\
\hline \multirow{2}{*}{1886} & Dysprosium & de Boisbaudran & Discovered in France \\
\hline & Germanium & Winkler & Discovered in Prussia \\
\hline 1896 & Europium & Demarçay & Discovered in France \\
\hline \multirow{2}{*}{1898} & Polonium & Curie & Isolated by Mme. Curie and Debierne in 1910 \\
\hline & Radium & Curie & Isolated by Mme. Curie and Debierne in 1910 \\
\hline 1899 & Actinium & Debierne & Isolated by Giesel in 1902 \\
\hline
\end{tabular}

\section{The Industrial Production of Aluminum}

Agreat technological advance was the invention of the dynamo in the 1870 's that made available electricity in bulk which encouraged the expansion of electrolytic copper refining to supply the pure copper needed for the electrical industry. Another important application of electricity was in the electrolytic production of aluminum. Once aluminum was available inexpensively, it was used for reducing other oxides to metals. Thus, chromium and manganese were prepared a few years later by this technique.

\section{$\mathrm{X}$-Rays and Radioactivity}

In 1895 x-rays were discovered by Wilhelm Conrad Roentgen (1845-1923) followed by the discovery of radioactivity in 1898 by Antoine Henri Becquerel (1852-1908) which was responsible for the discovery of polonium and radium [3] shortly afterwards by Marie Curie (1867-1934). A year later, André Debièrne (1874-
1949) a co-worker with Curie discovered and isolated actinium.

\section{Metals of the Twentieth Century}

Elements discovered in the $20^{\text {th }}$ century are those which are very rare or do not occur in nature (Table 4). Elements beyond plutonium were discovered at the Lawrence Radiation Laboratory, University of California from 1944 to 1961 by Seaborg, McMillan, and Ghiorso:
A. 1944, americium and curium
B. 1949, berkelium
C. 1950, californium
D. 1952, einsteinium
E. 1956, nobelium
F. 1961, lawrentium 
Table 4: Twenty century metals.

\begin{tabular}{|c|c|c|c|}
\hline Year & Metal & Discoverer & Remarks \\
\hline 1907 & Lutetium & Urbain & Discovered in France \\
\hline 1917 & Protactinium & $\begin{array}{c}\text { Hahn and Meit- } \\
\text { ner }\end{array}$ & Isolated by von Grosse in 1934. \\
\hline 1923 & Hafnium & $\begin{array}{c}\text { Coster and } \\
\text { Hevesy }\end{array}$ & Isolated by van Arkel and de Boer in 1925 \\
\hline 1924 & Rhenium & $\begin{array}{c}\text { Noddack, Tacke, } \\
\text { and Berg }\end{array}$ & Discovered in Germany \\
\hline 1937 & Technetium & Segre & $\begin{array}{c}\text { By bombardment of molybdenum with } \alpha \text {-particles; later on, found in } \\
\text { uranium fission components }\end{array}$ \\
\hline 1939 & Francium & Perey & Discovered in France \\
\hline $1940-$ & Trans-uranium & Deaborg et al. & Discoved in USA \\
\hline 1961 & metals & Seabored in USA \\
\hline 1945 & Promethium & $\begin{array}{c}\text { Glendenin and } \\
\text { Merinsky }\end{array}$ & Discovered \\
\hline
\end{tabular}

\section{Development of Radiochemistry}

Radiochemists played an important role in separating the individual radioelements, their identification, and their arrangement in series. New methods of measurements such as the Geiger counter and the gamma scintillation counter replaced the gold leaf electroscope. Radiations from radioactive substances were identified as alpha, beta, and gamma. As a result, two very rare radioactive metals: protactinium and francium were discovered. Protactinium was discovered in $1917-18$ by Otto Hahn (18791968) and Lise Meitner (1878-1968) in Germany the new element was part of the decay chain of uranium-235.

Francium was discovered in 1939 at Curie Institute in Paris, France by Marguerite Perey (1909-1975) from which the element takes its name. It was discovered during the purification of a sample of actinium 227. It is extremely rare, with trace amounts found in uranium and thorium ores, where the isotope francium-223 continually forms and decays.

\section{The Discovery of Lutetium}

Lutetium, element 71, was discovered spectroscopically in 1907 by the French chemist Georges Urbain (1872-1938) (Figure 3) who named it after Lutia the Roman name of the place where Paris was founded. It was identified by Bohr as a rare earth and not as a member of Group IV.

\section{Quantum Theory}

The quantum theory by Max Planck (1858-1947) is based on the principle that energy like matter is also composed of minute quantities called quanta, i.e., energy is not continuous but occurs in small parcels. This allowed the understanding of the movement of electrons [4] in the atom by Niels Bohr (1885-1962), the hypothesis of the formation of electron shells, and the explanation of emission spectra.

\section{Electronic Structure of Rare Earths}

In 1922 Bohr elucidated the electronic structure of the rare earths. The 14 rare earth elements were identified as "inner transition metals" and were assigned a special place in the Periodic Table that became known as "lanthanides". In this group the two outermost electronic shells are filled with the same number of electrons, and it is in the third shell that the number of electrons is increased gradually. This explained the close similarity of the members of this group in their chemical behavior. Bohr concluded that element 72 which occurs after lutetium must be tetra-valent rather than trivalent and must belong to the zirconium family and not the rare earths. He advised his co-workers in his laboratory to search for this element in zirconium ores.

\section{X-Ray Analysis}

X-ray spectrum analysis by Henry Moseley (1887-1915) in 1914 led to the discovery of two metals: hafnium and rhenium.

\section{Discovery of The Neutron}

James Chadwick (1891-1974) in Cambridge in 1932 explained the experiments of Frédéric Joliot (1900-1958) and Irène Curie (1897-1957) in Paris by supposing that alpha particles were knocking neutral particles out of the nuclei of the beryllium atom and that these neutral particles were in turn knocking protons out of the paraffin. In this way the neutron was discovered.

\section{Neutron Capture}

In 1934, Enrico Fermi (1901-1954) in Rome discovered that neutrons may be captured by atoms and that the frequency of capture increases when they are slowed down by passing them through a hydrogen-rich material such as paraffin or water. He was thus able to produce atoms of higher atomic weights than those bombarded. For example, on bombarding cobalt with neutrons he 
was able to produce nickel. When, however, he and his coworkers bombarded uranium with neutrons, they obtained more than one radioactive product. Following the same line of thought as in their previous experiments they suggested that one of these products was formed by neutron capture, i.e., that it was a trans-uranium element or element number 93. Fermi put the new element under rhenium in the Periodic Table and called it eka-rhenium (Figure 8).

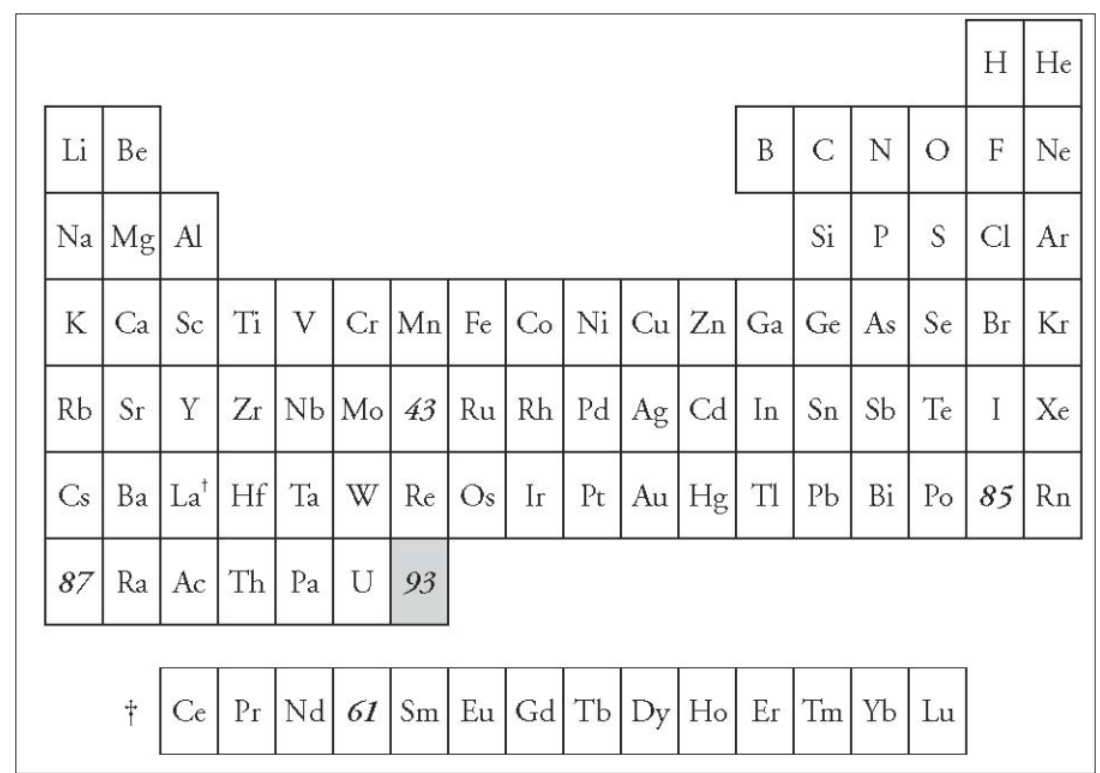

Figure 8: Eka-rhenium according to Fermi, 1934.

Fermis' paper naturally attracted the attention of Ida Noddack the discoverer of rhenium because it dealt with another element in the manganese group. Soon afterward, she published a paper which showed that Fermi's experimental evidence was incomplete. Her argument was as follows: when atoms are bombarded by protons or alpha particles, the nuclear reactions that take place involve the emission of an electron, a proton, or a helium nucleus and the mass of the bombarded atom suffers little change. When, however, neutrons are used, new types of nuclear reaction should take place that are completely different from those previously known It would be reasonable to propose that they break down into numerous large fractions. Here she conceived the idea of nuclear fission.

\section{Discovery of Uranium Fission}

Fermi's experiments were repeated by Otto Hahn (1879-1968) and his coworkers in Berlin. They confirmed Fermi's conclusions and published a series of papers on extensive radiochemical separations of the so-called trans-uranium elements. The results, however, became so contradictory that after five years of intensive research and extensive publication the concept of trans-uranium elements had to be abandoned. Hahn then announced in January 1939 the definite formation of barium during the bombardment of uranium and started speculating about the mechanism of its formation. Hahn could not accept the new idea that the uranium atom was split into two fragments. It was Lise Meitner in Sweden who finally explained the results of the work as fission, a few months after she was forced to leave Germany in 1939.

\section{Cyclotron}

The cyclotron was invented by Ernest O. Lawrence (1901-1958) of the University of California, Berkeley, where it was first operated in 1932. By its means technetium and the trans-uranium metals were discovered. In 1937 the Italian physicists Emilio Segrè (19051989) and his co-worker C. Perrier announced the detection of the element with atomic number 43 in trace amounts in a molybdenum target which has been bombarded in the cyclotron for several months with a strong deuteron beam. They called this new element technetium deriving the name from the Greek word for "artificial".

\section{Transuranium}

After elucidating the electronic structure of the trans-uranium which resembled that of the lanthanides, Seaborg (1912-1999) proposed a second series of inner transition metals similar to the lanthanides that became known as "actinides". He changed the Periodic Table of 1945. Thus, uranium was removed from Group VI to become a member of this new group.

\section{Promethium}

The existence of a rare earth element between neodymium and samarium was predicted by Brunauer. This was confirmed in 1914 by Henry Moseley who, having measured the atomic numbers of all the elements then known, found there was no element with atomic number 61. This element was discovered by Glendenin, Marinsky, and Coryell in 1945 at Oak Ridge National Laboratory in uranium fission products and named "promethium". Promethium does not occur in nature.

\section{Metallurgy in the Past Decades}

Word War II ended by the use of atomic bomb. The bomb was the result of Manhattan Project in USA in 1940s which played an important role in developing extractive metallurgy for the production of uranium. It was responsible for advancing the 
technology of metallothermic reactions, introducing new leaching processes, new precipitation methods, new reagents, ion exchange technology, and solvent extraction.

For the peaceful uses of atomic energy, uranium and transuranium elements were thoroughly studied, and the chemistry of other metals such as beryllium, boron, cadmium, zirconium, hafnium, rare earths, etc., became widely known. For the sake of conveniently outlining these developments, extractive metallurgy is divided into three sectors: pyro-, hydro-, and electrometallurgy. However, it is not possible to separate the three sectors since in general all three may be involved in the recovery of a particular metal.

\section{References}

1. Habashi F (2003) Metals from ores: An introduction to extractive metallurgy. Published by Métallurgie Extractive Québec, Québec City, Canada.

2. Habashi F (2010) Metals: typical and less typical, transition and inner transition. Foundations of Chemistry 12(1): 31-39.

3. Habashi F (2015) The story of metals, two volumes. Published by Métallurgie Extractive Québec, Québec City, Canada.

4. Habashi F (1997) Handbook of extractive metallurgy, Wiley-VCH, Weinheim, Germany, Vol. 4. 